\title{
PENINGKATAN HASIL BELAJAR PENDIDIKAN JASMANI MELALUI MODEL PEMBELAJARAN KOOPERATIF TIPE JIGSAW SISWA SDN SAMBIGEDE 03 SUMBERPUCUNG MALANG
}

\author{
Sriyatin ${ }^{1}$, Adi Sucipto ${ }^{2}$, Sulikan $^{3}$ \\ ${ }^{1}$ Dinas Pendidikan Kabupaten Malang \\ Email: sriyatin12@gmail.com \\ ${ }^{2}$ Pascasarajana IKIP Budi Utomo Malang \\ Email: adi.sucito@budiutomomalang.ac.id \\ ${ }^{3}$ Fakultas Pendidikan Ilmu Eksakta dan Keolahragaan \\ Email: sulikan@budiutomomalang.ac.id
}

\begin{abstract}
ABSTRAK
Kurangnya variasi dalam pembelajaran pendidikan jasmani membuat siswa bosan dan tidak semangat dalam mengikuti pelajaran. Karena itu diperlukan model pembalajaran yang menarik sehingga siswa menjadi lebih semangat dalam mengikuti pelajaran. Model yang terapkan dalam penelitian ini adalah Pembelajaran Kooperatif Tipe Jigsaw.Tujuan penelitian ini adalah: (1) untuk meningkatkan hasil belajar pendidikan jasmani dengan menggunakan model pembelajaran kooperatif tipe jigsaw IIpada siswa kelas V SDN Sambigede 03 Sumberpucung Malang. Hasil penerapan model pembelajaran kooperatif tipe jigsaw pada kondisi awal atau hasil prasiklus menunjukkan ketidak tuntasan siswa dalam pembelajaran jasmani sebesar $40 \%$, kemudian diberikan treatment pada siklus I dan II dengan menggunakan model jigsaw mengalami peningkatan ketuntasan mencapai $57 \%$, dan pada siklus II ketuntasan mencapai $77 \%$.
\end{abstract}

Kata kunci: Pembelajaran, Model Kooperatif, Tipe Jigsaw, Hasil belajar Pendidikan jasmani

\begin{abstract}
Lack of variation in physical education education makes students bored and not enthusiastic in following the lesson. Because it requires an interesting model of learning so that students become more spirit in following the lesson. The model that applied in this research is Jigsaw model of cooperative learning model. The purpose of this study are: (1) to improve the learning outcomes of physical education by using cooperative learning model type jigsaw II in grade 5 students SDN Sambigede 03 Sumberpucung Malang. The result of applying of Jigsaw model of cooperative learning model at initial condition or prasiklus result showed students' incompleteness in physical learning by 40\%, then given treatment in cycle I and II using jigsaw model experiencing a 57\% improvement of mastery, and on cycle II completeness reached $77 \%$.
\end{abstract}

Sriyatin, Adi Sucipto, Sulikan . Peningkatan Hasil Belajar Pendidikan Jasmani Melalui Model Pembelajaran Kooperatif Tipe Jigsaw Siswa SDN Sambigede 03 Sumberpucung Malang 
Keywords: Learning, Cooperative Model, Jigsaw Type, Learning Outcomes

\section{PENDAHULUAN}

Pendidikan Jasmani merupakan proses pendidikan yang memanfaatkan aktivitas jasmani yang direncanakan secara sistematik, bertujuan untuk meningkatkan individual secara organik, neuromuscular, perceptual, kognitif, sosial dan emosional (Depdiknas: 2003). Pendidikan jasmani pada dasarnya merupakan bagian integral dari sistem pendidikan secara keseluruhan. Oleh karenaitu pelaksanaan pendidikan jasmani harus diarahkan pada pencapaian tujuan tersebut. Tujuan pendidikan jasmani bukan hanya mengembangkan ranah jasmani, tetapi juga mengembangkan aspek, kebugaran jasmani, keterampilan berfikir kritis, stabilitas emosional, ketrampilan sosial, penalaran dan kegiatan moral melalui kegiatan aktifitas jasmani dan olahraga.

Pendidikan Jasmani adalah bentuk pendidikan yang memberikan perhatian pada pengajaran pengetahuan, sikap dan keterampilan gerak manusia (Seaton, 1974). Pendidikan Jasmani mempunyai keunikan dibandingkan dengan pendidikan yang lain, yaitu yang memberikan kesempatan untuk mengembangkan karakter dan sifat sosial yang lebih besar untuk mewujudkan tujuan pembelajaran.

Siswa sekolah dasar merupakan masa perkembangan dan pertumbuhan. Oleh karena itu, dalam membelajarkan pendidikan jasmani diharapkan dapat merangsang perkembangan dan partumbuhan siswa. Untuk mencapai hal tersebut, maka materi-materi dalam pendidikan jasmani dari sekolah tingkat paling rendah hingga atas telah diatur dalam kurikulum pendidikan jasmani.

Salah satu masalah utama dalam pendidikan jasmani adalah belum efektifnya pengajaran penjas di sekolah-sekolah. Kondisi ini disebabkan oleh beberapa faktor diantaranya ialah terbatasnya kemampuan guru dalam memberikan materi pelajaran dan juga terbatasnya sarana dan prasarana yang digunakan dalam mendukung proses pembelajaran penjas. Selain itu juga diakibatkan karena kurang semangatnya siswa dalam kegiatan pembelajaran pendidikan jasmani. Begitu juga masalah ini terjadi pada pembelajaran pendidikan jasmani di kelas V SDN Sambigede 03 Sumberpucung Kabupaten Malang. Sehingga peneliti mencoba malakukan penelitian dengan menerapkan modelpembelajarankooperatiftipejigsaw. Hal ini dengan tujuan untuk meningkatkan hasil pembelajaran pendidikan jasmani. Peran guru dalam menggunakan pembelajaran kooperatif

\footnotetext{
Sriyatin, Adi Sucipto, Sulikan . Peningkatan Hasil Belajar Pendidikan Jasmani Melalui Model Pembelajaran Kooperatif Tipe Jigsaw Siswa SDN Sambigede 03 Sumberpucung Malang 
tipejigsawa $\mathrm{d}$ a $\mathrm{l}$ a h sebagai fasilitator dan pembimbingkegiatan siswa untuk mencapai peningkatan hasil belajar.

Berdasarkan identifikasi masalah di atas maka rumusan masalah dalam penelitian ini adalah: ketuntasan hasil belajar pendidikan jasmani SDN Sambigede 03 Sumberpucung Malang Tahun 2016/2017 masih rendah yaitu 55\% . Untuk menyelesaikan masalah dia atas perlu dicari penyebabnya dan perlu metode pembelajaran yang bisa meminimalisasi permasalahan di atas. Salah satu metode pembelajaran yang diyakini mampu mengatasi permaslahan di atas adalah metode pembelajaran Kooperatif tipe Jigsaw. Metode ini menuntut siswa untuk aktif dalam kegiatan pembelajaran.Tujuan penelitian ini adalah: (1) untuk mening-katkan hasil belajar pendidikan jasmani dengan menggunakan model pembelajaran kooperatif tipe jigsaw II pada siswa kelas V SDN Sambigede 03 Sumberpucung Malang.

\section{Metode Pembelajaran kooperatif}

Menurut Jingjing Li (2017) "Cooperative Learning has proven to be effective. Presently it is utilized in schools and universities in all over the world with students covering all ages". Jadi model belajar kooperatif telah terbukti efektif sehingga dapat digunakan di sekolahsekolah dan universitas di seluruh dunia dengan siswa yang mencakup segala usia.

Salah satu model pembelajaran kooperatif yang dapat diterapkan dalam pembelajaranpendidikan jasmani di sekolah adalah model cooperative learning tipe jigsaw. Padamodel pembelajaran kooperatif tipe Jigsaw, siswa dikelompokkan menjadi kelompok kecil yangberjumlah 4-6 orang sebagai kelompok asal, setiap anggota kelompok mendapatkan tugas spesifikyang berbeda satu dengan yang lain. Setiap anggota kelompok yang mendapatkan tugas yang samakemudian berkumpul dengan anggota kelompok lainnya membentuk kelompok ahli untuk salingbekerjasama dalam memahami atau menyelesaikan tugas yang diberikan. Setelah siswa bekerja didalam kelompok ahli, setiap anggota kelompok ahli kemudian kembali ke kelompok asal untukmenyampaikan tugas yang telah mereka pahami kepada anggota kelompok lainnya sehingga seluruhanggota kelompok asal memiliki pemahaman yang sama dan menyeluruh (Slavin, 2008). Selain itu Ciri-ciri pembelajaran kooperatif ini Seperti yang dikemukakan oleh Carin (1993) bahwa salah satu ciri pembelajaran kooperatif adalah, selamaproses belajar mengajar Sriyatin, Adi Sucipto, Sulikan . Peningkatan Hasil Belajar Pendidikan Jasmani Melalui Model Pembelajaran Kooperatif Tipe Jigsaw Siswa SDN Sambigede 03 Sumberpucung Malang 
berlangsung, guru membantu melatihkan dan mengembangkan keteram-pilan-keterampilan interpersonal siswa dalam kelompok.

Dalam pembelajaran pendidikan jasmani ini tidak terlepas dari perilaku kognitif dan motorik. Ada beberapa tahapan perkembangan kognitif dalam pembelajaran pendidikan jasmani, yaitu:

\section{Tahap perkembangan kognitif (Piaget)}

Menurut Piaget, proses belajar seseorang akan mengikuti pola dan tahap-tahap perkembangannya sesuai dengan umurnya. Pola dan tahap-tahap ini bersifat hirarkhis, artinya harus dilalui berdasarkan urutan tertentu dan seseorang tidak dapat belajar sesuatu yang berada di luar tahap kognitifnya (Piaget dalam Budiningsih,A. 2004).

Tahapan perkembangan berpikir anak merujuk konsep yang dikembangkan oleh Piaget. Pada tahapan usia dini untuk anak yang ikut pembelajaran berada pada operasional konkrit (usia 7-11 tahun) dan sampai juga mendekati cara berpikir formal; operasional. Pada dasarnya ada 4 tahapan yakni sensorimotor, pra opera-sional, operasional konkrit dan operasional formal. Terkait empat tahapan tersebut maka pada kajian ini difokuskan pada tahap operasional konkrit yang memang berada pada tahapan anak yang ikut pembelajaran jasmani. Tahap Operasional konkret (usia 7 - 11 tahun), pada saat itu anak sudah belajar tentang aturan-aturan sederhana dalam kehidupan-nya. Pada tahapan ini seorang anak tidak hanya mampu mempraktikkan secara aktivits fisik, namun juga sudah bisa mereka lakukan secara kognisi. Ciri khas utama pada tataran ini adalah anak sudah mampu mengurutkan berbagai kategori. Misalnya membedakan ukuran bola yang bevariasi dari bola kecil sampai bola besar, dan berapa jumlah masing-masing bola. Memahami cara bermain, teknik bermain, taktik bermain dan aturan-aturan yang ada dalam permainan dari yang sederhana sampai yang kompleks dan variatif. Sedangkan Gagna dan Briggs (1992) Pembelajaran adalah seperangkat peristiwa yang mempengaruhi si belajar sedemikian rupa sehingga si belajar itu memperoleh kemudahan dalam berinteraksi berikutnya dengan lingkungan.

Tahapan perkembangan kongitif ini siswa berada pada kemampuan yang sangat mendukung pemahaman. Oleh karena itu memahami suatu konsep dasar teknik bermain, aturan bermain, dan taktik bermain dalam permainan sepakbola harus dikerjakan.

\footnotetext{
Sriyatin, Adi Sucipto, Sulikan . Peningkatan Hasil Belajar Pendidikan Jasmani Melalui Model Pembelajaran Kooperatif Tipe Jigsaw Siswa SDN Sambigede 03 Sumberpucung Malang 


\section{Pengembangan Ranah Kognitif Pada Taksonomi Bloom}

Benjamin S. Bloom (1981) bahwa pengelompokkan tujuan pendidikan itu harus senantiasa mengacu kepada tiga jenis domain (daerah binaan atau ranah) yang melekat pada diri peserta didik, yaitu: a) Ranah proses berfikir (cognitive domain) b) Ranah nilai atau sikap (affective domain) c) Ranah keterampilan (psychomotor domain)

Pada saat anak berada pada tahap operasional konkrit, maka anak diajak untuk mengetahui, memahami, sampai pada mampu menilai atau lebih tinggi lagi mampu mencipta. Kemampuan dasar mengurutkan dan menghubungkan sangat penting diketahui, agar konsep yang diberikan bisa tepat. Level terendah pada taksonomi Bloom (1981) dapat digunakan dengan memilih kata-kata operasional yang tepat sehingga mampu memberikan ciri khas pemberian konsep yang tepat dan mudah dipahami. Ada 3 ranah dalam taksonomi Bloom seperti dijelaskan berikut ini, yakni, a. Ranah kognitif yaitu mengingat, mema-hami, menerapkan, menganalisis, menilai, membuat, b. Ranah psikomotorik: meliputi, persepi, kesiapan, reaksi yang diarahkan, reaksi natural (mekanisme), adaptasi, reaksi yang kompleks kreativitas, c. Ranah afektif: meliputi penerimaan, responsif, nilai yang dianut (nilai diri), organisasi dan karakterisasi.

Cukup banyak kata-kata operasional yang bisa digunakan dalam masa operasional konkrit yang sesuai dengan ranah kognitif anak. Pemilihan kata operasional akan menjadi ciri khas pemberian konsep dan audiovisual yang spesifik dan membedakan dengan metode pembelajaran lainnya.

Pendidikan jasmani bukanlah aktivitas jasmani itu sendiri, tetapi untuk mengembangkan potensi siswa melalui aktivitas jasmani. Karena itu pendidikan Jasmani merupakan bagian integral dari sistem pendidikan secara keseluruhan. Sehingga pelaksanaan pendidikan jasmani harus diarahkan pada pencapaian tujuan pendidikan tersebut. Untuk mencapai tujuan pembelajaran penjaskes diaperlukan metode, model dan pendekatan yang sesuai dengan kebutuhan situasi dan konsisi anak didik dan lingkungan.

Modifikasi model pembelajaran Penjaskespenting untuk diketahui dan dilaksanakan oleh para guru pendidikan jasmani. Dengan modifikasi siswa mempe-roleh kepuasan dalam mengikuti pelajaran, meningkatkan kemungkinan keberhasilan dalam partisipasi, siswa dapat melakukan pola gerak secara benar (Lutan \& Sumardianto, Sriyatin, Adi Sucipto, Sulikan . Peningkatan Hasil Belajar Pendidikan Jasmani Melalui Model Pembelajaran Kooperatif Tipe Jigsaw Siswa SDN Sambigede 03 Sumberpucung Malang 
2000).

Terkait hasil belajar menurut Hamalik (2002) yaitu terjadinya perubahan tingkah laku pada diri siswa, yang dapat diamati dan diukur dalam perubahan pengetahuan sikap dan keterampilan. Perubahan dapat diartikan terjadinya peningkatan dan pengembangan yang lebih baik dibanding-kan dengan sebelumnya. Sedanagkan hasil belajar menurut Sudjana (1990) adalah kemampuan yang dimiliki siswa setelah ia menerima pengalaman belajarnya.

Gagne (1985) mengungkapkan ada lima kategori hasil belajar, yaitu: informasi verbal, kecakapan intelektual, strategi kognitif, sikap dan keterampilan. Sementara belum mengungkap tiga tujuan pengajaran yang merupakan kemampuan seseorang yang harus dapat dicapai dan merupakan hasil belajar yaitu: kognitif, afektif, dan psikomotorik (Sudjana,1990). Pengertian hasil belajar dari beberapa pakar diatas dapat disimpulkan bahwa hasil belajar adalah suatu kemampuan atau keterampilan yang dimiliki oleh siswa setelah siswa tersebut mengalami aktivitas belajar. Melalui metode pembelajaran ini diharapakan dapat meningkatkan prestasi belajar siswa. Pembelajaran kooperatif berarti working together to accomplish shared goals (bekerjasama untuk mencapai tujuan bersama). Kooperatif berarti setiap anggota saling berusaha mencapai hasil yang nantinya bisa dirasakan oleh semua anggota kelompok. Pembelajaran koope-ratif sebagai kelompok kecil siswa yang bekerjasama dalam satu tim untuk mengatasi suatu masalah, menyelesaikan sebuah tugas, atau mencapai satutujuan bersama.

\section{METODE}

Rancangan penelitian ini merupakan Penelitian tindakan kelas dengan dua siklus.Salah satu ciri Classroom Action Research adalah cyclic atau adanya langkah-langkah yang terukur dan terencana dalam sebuah siklus. Setiap siklus melalui fase-fase Planning (Perencanaan), Acting (Tindakan), Observing (Pengamatan), dan Reflecting (Refleksi) (Kemmis dan Mc Taggart, 1992).

Pelaksanaan tindakan pembelajaran dengan model pembelajaran kooperatif tipe Jigsaw. Subjek Penelitian ini meng-gunakan siswa kelas V SDN Sambigede 03 Sumberpucung Kabupaten Malang Tahun 2016/2017, berjumlah 30 siswa. Penelitian ini dilakukan mulai 29 Agustus sampai dengan 15 Oktober 2016. Tempat di SDN Sambigede 03 Sumberpucung Kabupaten Malang.

\footnotetext{
Sriyatin, Adi Sucipto, Sulikan . Peningkatan Hasil Belajar Pendidikan Jasmani Melalui Model Pembelajaran Kooperatif Tipe Jigsaw Siswa SDN Sambigede 03 Sumberpucung Malang 


\section{Pelaksanaan Tindakan}

Pertama-tama guru menjelaskan materi di dalam kelas, tentang bagaimana cara mengoper dan mengontrol bola dengan baik, setelah itu guru juga menjelaskan cara penerapan model jigsaw di dalam kelas, jigsaw yang diterapkan sesuai Setelah siswa memahami maka guru membawa siswa ke lapangan, kemudian membariskan siswa, presensi dan apersepsi mulai dari ucapan salam, penyampaian materi konsep dan tujuan pembelajaran. Kemudian langsung melakukan pemanasan dinamis. Untuk siklus pertama kehadiran siswa berjumlah 30 orang. Untuk menerapkan model kooperatif jigsaw guru membagi mereka menjadi 5kelompok yang terdiri dari 6 orang setiap kelompok. Dalam penera-pan model jigsaw ada kelompok ahli dan asal, yang mana kelompok ahli mengajarkan cara mengoperbola dan mengontrol bola yang benar pada setiap kelompok. setelah itu mereka kembali kepada kelompoknya sendiri.

PengamatanTindakan: Pengamatan dilakukan untuk mengamatiproses pembelajaran dibuat dengan bergradasi 1, 2, 3, dan 4, dengan ketentuan:1 - TidakBaik, 2 - Kurang Baik, 3 - Cukup Baik, 4 Baik.

Instrumen penelitian: Instrumen peneli-tianyangdigunakanuntuk mengumpul-kan data dengan menggunakan rubrik penilaian hasil belajar pasing dan stoping per-mainan sepakbola dengan rentangan nilai bergradasi 1, 2, 3, dan 4, dengan ketentuan (1-TidakBaik, 2 Kurang Baik, 3 - Cukup Baik, 4 - Baik). 


\section{HASIL DAN PEMBAHASAN}

Berdasarkanobservasi hasil belajar siklus Isiswa yang mampu mengoper dan mengontrol bola dengan baik dan benar hanya 13 siswa atau $43 \%$, sedangkan yang tidak tuntas atau tidak bisa mengoper dan mengontrol 17 siswa atau $57 \%$. Untuk lebih jelasnya paparkan hasil observasi pada siklus 1 sebagai berikut:

Tabel 1. Hasil Nilai Presentase Siklus 1

\begin{tabular}{|l|c|c|c|c|}
\hline \multirow{2}{*}{ Variabel } & \multicolumn{2}{|c|}{ Tidak Tuntas } & \multicolumn{2}{c|}{ Tuntas } \\
\cline { 2 - 5 } & Jumlah & Persen & Jumlah & $\%$ \\
\hline $\begin{array}{l}\text { Keterampilan Mengoper } \\
\text { dan Mengontrol Bola }\end{array}$ & 17 & $57 \%$ & 13 & $43 \%$ \\
\hline
\end{tabular}

Pada Tabel 1.1 di atas dapat diketahui nilai ketuntasan hasil belajar adalah 13 siswa yang mencapai nilai di atas KKM yaitu 43\%, dan yang belum tuntas 57\%. Presentasi diatas menunjukkan bahwasa pembelajaran pada siklus 1 masih belum memenuhi standar ketuntasan. oleh karena itu perlu dilanjutkan siklus 2 .

Sedangkanobservasi hasil belajar siklus IIsiswa yang mampu mengoper dan mengontrol bola dengan baik dan benar hanya 23 siswa atau $77 \%$, sedangkan yang tidak tuntas atau yang masih salah mengoper dan mengontrol7 siswa atau $23 \%$. Untuk lebih jelasnya paparkan hasil observasi pada siklus II sebagai berikut:

Tabel 2. Hasil Nilai Presentase Siklus 2

\begin{tabular}{|l|c|c|c|c|}
\hline \multirow{2}{*}{ Variabel } & \multicolumn{2}{|c|}{ Tidak Tuntas } & \multicolumn{2}{c|}{ Tuntas } \\
\cline { 2 - 5 } & Jumlah & Persen & Jumlah & $\%$ \\
\hline $\begin{array}{l}\text { Keterampilan Mengoper } \\
\text { dan mengontrol bola }\end{array}$ & 7 & $23 \%$ & 23 & $77 \%$ \\
\hline
\end{tabular}

Pada Tabel 1.2 di atas dapat diketahui nilai ketuntasan hasil belajar adalah 23 siswa dapat mencapai nilai di atas KKM, jika di presentasekan sebesar 77\%, sedangkan yang belum tuntas sebesar 7 orang siswa atau dapat dipresentasikan sebesar $7 \%$ sehingga dapat ditarik kesimpulan bahwasanya pembelajaran pada siklus IIsudahada kenaikan sebesar $20 \%$.

\section{PEMBAHASAN}

\footnotetext{
Sriyatin, Adi Sucipto, Sulikan . Peningkatan Hasil Belajar Pendidikan Jasmani Melalui Model Pembelajaran Kooperatif Tipe Jigsaw Siswa SDN Sambigede 03 Sumberpucung Malang 
Perbandingan setiap siklus mendes-kripsikan setiap perubahan yang dilakukan oleh siswa melalui penggunaan model pembelajaran kooperatif tipe jigsaw II. Perubahan ini berupapeningkatan hasil belajar peserta didik khususnya pada materi mengoper dan mengontrol bola.Siklus I dilaksanakan dalam dua kali pertemuan. dengan menggunakan model kooperatif tipe jigsaw. Slavin (2008) model jigsaw adalah model kooperatif dengan siswa dalam kelompokkelompok kecil yang terdiri dari empat sampai enam secara heterogen dan bekerjasama saling ketergantungan yang positif dan bertanggung jawab atas ketuntasan bagian pelaksanaan siklus satu.

Dari hasil pengamatan peneliti terhadap proses pembelajaran, dapat diketahui bahwa pembelajaran mengoper dan mengontrol bola pada siklus I masih terdapat kekurangan dan kelemahan. Kelemahan tersebut berasal dariguru, siswa, dan alat bantu pembelajaran yang digunakan dalam penelitian.

Kelemahan dari segi guru, yaitu pemberian umpan dari guru untuk membuat siswa aktif dalam pembelajaran masih kurang mendapat respon dari siswa, apersepsi yang diberikan masih belum memberi gambaran bagi siswa tentang materi yang sedang diajarkan, tanya jawab yang belum maksimal, dan belum adanya penguatan dari guru untuk meningkatkan motivasi belajar siswa. Kelemahan dari segi siswa, yaitu siswa tidak berkonsentrasi dan belum tampak aktif dan mengerti tentang menerapkan kooperatif tipe jigsaw hingga hasilnya belajar khususnya materi mengoper dan mengontrol bola kurang maksimal.

Nilai yang diperoleh dari siswa pada siklus I masih perluh ditingkatkan karena masih belum mencapai ketuntasan maksi-mal. oleh karena itu guru memberikan solusi yaitu tambahan media dan penguatan materi kepada siswa pada kelompok ahli. guru juga memberikan penghargaan pada setiap siswa yang berperan aktif dalam mengajarkan materi yang sesuai pada peserta didik. penggunaan model pembela-jaran kooperatif tipe jigsaw lebih dipersiapkan dalam siklus II.

Berdasarkan hasil refleksi pelaksanaan tindakan I, dilakukan perbaikan kelemahan proses pembelajaran dengan melakukan tindakan siklus II. Akhir dari proses pembelajaran pada siklus II menunjukan adanya peningkatan kemampuan mengoper dan mengontrol bola. Keberhasilan siklus II ini dapat dilihat dari perubahan tingkah laku siswa dalam proses dan mengikuti jalannya pembelajaran sebuah materi yang ditawarkan oleh guru. Contoh kongkritnya siswa dari Sriyatin, Adi Sucipto, Sulikan . Peningkatan Hasil Belajar Pendidikan Jasmani Melalui Model Pembelajaran Kooperatif Tipe Jigsaw Siswa SDN Sambigede 03 Sumberpucung Malang 
kelompok ahli berhasil mengajarkan cara mengontrol dan menggiring bola pada kelompok asal tanpa bantuan guru. Dengan demikian penelitian tindakan kelas pada siswa kelas V SDN Sambigede 03 Kecamatan Sumberpucung dengan penerapan model pembelajaran kooperatif tipe jigsaw II dapat dikatakan berhasil meningkatkan hasil belajar pendidikan jasmani khususnya keterampilan menendang dan mengoper bola dalam permaiann sepakbola. Hal ini sesuai dengan penelitian Hidayat (2017) bahwa model pembelajaran kooperatif tipe jigsaw dapat meningkatkan keterampilan olahraga mata pelajaran beladiri terutama taekwondoyang signifikan. Hasil penelitian juga senada dengan dengan hasil penelitian Affandy (2017) bahwa terdapat pengaruh yang signifikan penerapan model pembelajaran kooperatif tipe jigsaw terhadap hasil belajar teknik dasar dribbling dan passing sepakbola pada siswa SMP.

\section{SIMPULAN}

Berdasarkan analisis data yang telah dilakukan dan pembahasan yang telah diungkapkandiperoleh simpulan sebagai berikut:Penerapan model pembelajaran tipe Jigsaw II dapat meningkatkan hasil belajar pendidikan jasmani siswa kelas V SDN Sambigede 03 Sumberpucung Kabupaten Malang. Khususnya keterampilan menendang dan mengontrol bola dalam permainan sepakbola. Hasil sebelum pelaksanaan tindakan nilai siswa masih di bawah KKM, ketuntasan klasikal hanya $40 \%$ setelah dilakukan penerapan model kooperatif tipe jigsaw II meningkat menjadi $77 \%$.

\section{Saran}

Berdasarkan hasil penelitian maka dapat diajukan beberapa saran antara lain:

1. Guru harus bisa memastikan siswa dapat memahami dan mengerti materi serta model yang diterapkan dalam setiap pembelajaran.

2. Untuk pencapaian kualitas hasil belajar dengan model pembelajaran kooperatif tipe jigsaw diperlukan persiapan yang matang, misalnya pembagian kelompok secara heterogen.

3. Keaktifan siswa hendaknya dapat dikontrol tidak hanya dilapangan tetapi juga di kelas.

4. Untuk mencapai kualitas proses belajar mengajar dan kualitas hasil belajar

\footnotetext{
Sriyatin, Adi Sucipto, Sulikan . Peningkatan Hasil Belajar Pendidikan Jasmani Melalui Model Pembelajaran Kooperatif Tipe Jigsaw Siswa SDN Sambigede 03 Sumberpucung Malang 
5. dengan model pembelajaran kooperatif tipe jigsaw diperlukan persiapan perangkat pembelajaran yang cukup memadai.

\section{DAFTAR PUSTAKA}

Affandy, Sugeng 2017. Penerapan Model Pembelajaran Kooperatif Tipe Jigsaw Terhadap Hasil Belajar Teknik Dasar Dribbling Dan Passing Sepakbola.Jurnal Pendidikan Olahraga dan Kesehatan. Vol 5, No 3 (2017). 496 - 500.http://jurnalmahasiswa.unesa.ac.id Carin, A. 1993. Teaching Modern Science. New York: Macmillan Publishing Company.

Bloom, Benjamin S,. 1981. Evaluation to improve Learning.Published December 1st 1981 by McGraw-Hill Companies.

Budiningsih,Asri. 2004. Belajar dan Pembelajaran. Penerbit Rinika Cipta, Yogyakarta. Hal. 35-39.

Depdikbud.1994.Garis-garisBesarProgramPengajaran.Jakarta.

Gagne, R. M. 1985. The Conditions of Learning. New York:Holt Renehart and Winston.

Hamalik, Oemar. 2003.Pendekatan Baru Strategi Belajar Mengajar berdasarkan CBSA : Bandung : Sinar Baru Algesindo.

Hidayat, C., Juniar, DT. 2017.Penerapan Model Cooperative Learning Tipe Jigsaw Terhadap Hasil Belajar Keterampilan Poomsae I Mata Kuliah Taekwondo, (JPJO)Vol 2, No 2

(2017) http://ejournal.upi.edu/index.php/penjas/index. p-ISSN : 2085-6180 e-ISSN : 2580-071X.

Jingjing Li a, Yumei Zhangb, Jiayu Manc, Yun Zhoud, Xiaojun Wua,b,. 2017. Two knowledge dissemination models with leader nodes on cooperative learning networks. Journal of Physica A. Vol 468: 740-749.

Kemmis, Stephen \& Taggart, Robin. 1992. The Action Research Planner, Victoria: Deakin University Press.

Lutan, Rusli. 1988. Belajar Keterampilan Motorik. Depdikbud, Ditjen Dikti Jakarta.

Lutan Rusli \& Sumardianto. 2000. Filsafat Olahraga: Depdikbud. Seaton,D.O.etal.1974.PhysicalEducationHandBook, Englewood.Cliffs.N6th.Prentice-hall,inc.

Slavin, Robert E. (2008). Cooperative Learning Theory, research, and Practice.USA : The Jhons Hopkins University. 
Sudjana, Nana. 1990. Teori-teori Belajar Untuk Pengajaran. Bandung: Fakultas EkonomiUI. 